\title{
Peran Konselor Dalam Meningkatkan Daya Ingat Belajar Siswa
}

\author{
Dini Fitriani ${ }^{*}$ Ifdil $^{2}$ \\ ${ }^{12}$ Universitas Negeri Padang, Sumatera Barat, Indonesia, \\ *) Correspondence regarding this article should be addressed to: Author address e-mail: \\ dinifitrianiii15@gmail.com
}

\begin{abstract}
Pendidikan merupakan salah satu upaya mengaktualisasika potensi diri yang dimiliki oleh individu. Baik itu potensi yang mendasar yang ada pada dirinya ataupun potensi-potensi yang ia terima saat ia mengalami proses belajar. Pada saat proses belajar individu menerima rangsangan dari stimulus-stimulus yang ada, dalam proses belajar belum ada faktor yang mendukung dan tidak mendukung berjalannya dengan lancar suatu proses belajar tersebut.Pada kenyataanya siswa tidak mampu dalam menjalankan dan mengembangkan potensi potensi yang ada pada dirinya, terkadang siswa tidak mampu mengimbangi faktor-faktor yang ada, salah satu nya adalah faktor yang sangat berpengaruh terhadap proses belajar sisswa adalah faktor daya ingta siswa tersebut. lemah atau kuatnya ssiswa dalam menginta pelajaran yanga da di tingkat pendidikannya.Bertolak dari permasalahn diatas, maka penulis akan membahas makalah ini dengan judul 'Peran Koselor dalam Meningkatkan Daya Ingat Belajar Siswa' yang bertujuan untuk membantu dan mengarahkan siswa agar mampu meningkatkan dan mengingat pelajaran-pelajaran dengan baik.
\end{abstract}

Keywords: Daya Ingat, Belajar,Peran Konselor dalam Daya Ingat.

Article History: Received on 01/03/2019; Revised on 04/04/2019; Accepted on 12/04/2019; Published Online: 30/04/2019.

This is an open access article distributed under the Creative Commons Attribution License, which permits unrestricted use,
distribution, and reproduction in any medium, provided the original work is properly cited. (C2019 by author.

\section{PENDAHULUAN}

Pendidikan merupakan salah satu faktor yang penting dalam meningkatkan taraf hidup manusia, selain itu juga menentukan maju mundurnya suatu bangsa, karenanya pemerintah Indonesia selalu memperhatikan masalah pendidikan disamping faktor lain yang menunjang keberhasilan pembangunan. Proses belajar itu sendiri telah dialami oleh individu sejak ia dilahirkan, hingga dewasa. Belajar adalah kegiatan yang berproses dan merupakan suatu usaha seseoang untuk memperoleh perubahan tingkah laku(Hanafy, 2014). Menurut Uno, H. B. (2012) "Belajar adalah ushaa yang dilakukan individu secara keseluruhan yang berasal dari pengalamannya".

Belajar merupakan suatu aktifitas mental atau psikis yang berlangsung dalam interaksi aktif dalam lingkungan yang menghasilkan perubahan-perubahan dalam pengetahuan, pemahaman, keterampilan, nilai dan sikap. Selanjutnya Hamalik (2011) menyatakan belajar adalah hasil dari pengalaman yang menyangkut pengetahuan ataupun sikap. berdasarkan pendapat diatas dapat disimpulkan bahwa belajar adalah perubahan yang terjadi pada diri individu baik perubahan tingkah laku, cara berfikir, 
keterampilan, bahkan aspek pribadi yang merupakan hasil latihan dan pengalaman. Senada dengan hal itu Menurut Slameto (2010) dalam hal ini belajar ada cara-cara efesien, banyak siswa yang gagal atau tidak mendapatkan hasil yang lebih baik dalam pembelajarannya karena mereka kebannyakan hanya mencoba menghafal pelajaran. Keberhasilan siswa dalam pembelajaran dipengaruhi oleh beberapa faktor diantaranya adalah daya ingat siswa dalam menerima pembelajaran di sekolah, karena di sekolah materi-materi yang ada dalam pembelajaran mengunakan daya ingat dalam memahami pelajaran yang ada mempengaruhi hasil belajar siswa.

\section{Pengertian Daya Ingat}

Menurut Davidoff (1988) ingatan adalah suatu sistem yang diawali dengan pengkodean yaitu menghubungkan masa lampau dengan masa sekarang setelah itu bila diperlukan atau m,engharapkan data dari masa lampau dikeluarkan kembali. Sejalan dengan itu Soemanto (1990) "mengingat adalah suatu ushaa aktif dengan cara pencaman'. Menurut Fudyartanta (2011)" ingatan adalah suatu usaha untuk menyimpan sesuatu untuk beberapa waktu dan kemudian mengeluarkannya kembali ketika dibutuhkan. ingatan merupakan unsur inti dari perkembangan kognitif, sebab segala bentuk belajar dari indivodu melibatkan ingatan. ingatan pada individu dimungkinkan untuk dapat menyimpan informasi yang diterima sepanjang waktu, sehingga tanpa ingatan, individu tidak dapat mengembangkan pribadinya sendiri, karena pemahaman diri sangat tergantung pada suatu kesadaran yang saling berhubungan dan terintegrasi antara semua bagian otak manusia. Hal itu hanya dapat terlaksana dengan adanya ingatan.

Dalam hal ini salah satu faktornya adalah daya ingat siswa tersebut karena dalam proses belajarnya siswa banyak menggunakan ingatan dalam mengingat pelajaran dalam proses belajarnya. Menurut Agus Sujanto (2014:41) "ingatakan adalah suatu hal yang dapat diterima disimpan dan disampaikan kembali". Sejalan dengan hal tersebut Abu Ahmadi (2009: 73) mengatakan ingatan ialah kekuatan diri individu untuk menerima, menyimpan, dan menghasilkan kembali kesan-kesan yang pernah terjadi.

\section{Sifat-Sifat Daya Ingat}

Daya ingat individu memliki sifat-sifat yang ada dalam sebuah daya ingat tersebut. (Ahmadi, 2009) menjelaskan beberapa sifat ingatan yaitu ingtaan yang mudah dan cepat, ingatan yang luas, ingatan yang teguh, ingatan yang setia dan ingatan mengabdi atau patuh. Senada dengan hal itu, Soemanto (1990) sifat-sifat dari pada ingatan yang baik adalah cepat, setia, kuat, luas, dan siap. Dapat dimaknai bahwa ada beberapa sifat-sifat daya ingat yang ada pada diri individu diantaranya adalah inagtan yang mudah dan cepat artinya seseorang dapat dengan mudah dalam menerima kesankesan.

Mengulang ingatan dapat memungkinkan orang dapat mengingat apa yang telah dipelajarinya, tetapi tidak berarti bahwa semua penyimapnan dalam memori ini akan tetap tinggal dengan baik, karena pada suatu saat penyimapann dalam memori otak akan dapat hilang,dalam hal ini orang mengalami kelupaaan. Seperti yang dijelaskan oleh Fudyartanta (2011)) "lupa adalah suatu hal yang telah disimpan dalam bawah sadar tetapi tidak dapat dikeluarkan kembali". Sejalan dengan itu Sujanto (2014) mengemukakan "lupa adalah ketika seseorang tidak mampu untuk menyampaikan 
kembali hal-hal yang telah diingat, padahal ingatan individu tersebut sehat". Oleh karena itu ketika seseorang tidak dapat menghasilkan tanggapan-tangapan yang pernah dialami, dan ingatannya sehat maka itu disebut dengan kelupaan. Berhubung dengan adanyaa ingatan yang berlainan dijelaskan bahwa ingatan itu bersifat indibidual dan unik artinya tiat-tiap siswa itu mempunyai tipe-tipe ingatan yang berbeda-beda.

\section{Pengertian Belajar}

Kemampuan belajar siswa sangat menentukan keberhasilannya dalam proses belajar, dalam psikologi defenisi belajar yang paling sering digunakan adalah perubahan perilaku yang relatif tetap sebagai hasil adanya pengalaman belajar . belajar meliputi tidak hanya mata pelajaran , tetapi juga penguasaan . kebiasaan, presepsi, kesenangan, minat, penyesuaian sosial, bermacam-macam keterampilan dan cita-cita. Belajar mengandung arti terjadinya perubahan dari presepsi dan perilaku, termasuk juga perbaikan Menurut Ahmadi, A. (2009) "belajar adalah suatu proses perubahan sikap yang terjadi dalam diri manusia". Sejalan dengan hal tersebut Hamalik, O (2011) belajar adalah suatu bentuk pertumbuhan atau perubahan dalam diri seseorang yang dinyatakan dalam cara-cara bertingkah laku yang baru yang diakibatkan dari pengalaman dan latihan. Syah, M. ( 2007) belajar adalah seluruh perubahan tingkah laku individu dari yang kurang baik menajdi lebih baik, dengan adanya perubahan tingkah laku ini adanya diakibatkan oleh lingkungan dan interkasinya dengan sesama individu.

\section{Prinsip-Prinsip Dalam Belajar}

Prinsip belajar dapat diperinci di dalam beberpa prinsip dasar. Prinsipprinsip belajar dapat dijadikan arah atau pedoman yang jelas di dalam belajar. Ahmadi, A. (2009) mengatakan prinsip-prinsip belajar yaitu: belajar adalah suatu proses kognitif dan adanya perubahan tingkah laku, dan adanya latihan yang dilakukan.

Slameto (2010) menyatakan prinsip-prinsip belajar terdiri dari, Berdasarkan prasyarat yang diperlukan untuk belajar, Sesuai hakekat belajar, Sesuai materi, Syarat keberhasilan siswa. Berdasarkan dari sumber tersebut dapat dijelaskan bahwa prinsip-prinsip dalam belajar itu banyak, akan tetapi prinsip belajar yang baik adalah prinsip belajar yang dapat dilaksanakan dalam situasi dan kondisi yang berbeda dan sesuai dengan tujuan keberhasilan siswa.

\section{Pengertian Konselor}

Konselor merupakan individu yang berkualifikasi dalam bidang konseling. Konselor menunjuk pada orang yang memberikan bantuan, menurut Hartono., \& Boy, S. (2012 ) konselor adalah seseorang yan memiliki keahlian daalam bidang pelayanan bimbingan dan konseling sebagai tenaga profesional.Senada dengan hal itu Menurut Undang-undang RI nomor 20 tahun 2003 tentang sistem pendidikan nasional pasal 1 ayat 6 (Hartono., \& Boy, S. 2012) disebutkan bahwa 
konselor sebagai pendiddik merupakan suatu tenaga kependidikan yang berpastisipasi dalam menyelenggarakan pendidikan .

menurut Hartono., \& Boy, S. (2012) pelayanan bimbingan dan konseling adalah suatu pemberian bantuan yang dilakukan seorang yang alhi kepada orang yang membutuhkan bantuan dengan tujuan memandirikan klien dalam penyelesaian masalahnya

\section{Usaha Konselor Dalam Meningkatkan Daya Belajar}

Dalam proses belajar seoraang siswa akan mengalami kesulitan-kesulitan tertentu, pengertian belajar itu sendiri telah dijelaskan di bab sebelumnya menurut Syah, M. (2007) belajar adalah tahapan perubahan tingkah laku individu yang relatif menetap sebagai suatu pengalaman yang saling berinteraksi yang melibatkan proses kognitif. Seorang siswa yang menajalani proses belajar disekolah mereka akan merasakan perubahan-perubahan yanga da pada dirinya seperti perubahan tingkah laku, penambahan materi atau pengetahuan yang dimilikinya, dalam proses belajar ini siswa sangat membutuhkan daya ingat yang baik untuk mengingat pelajaran-pelajaran yang telah dipelajarinya oleh karna ini daya ingat dangat berpengaruh dalam proses belajar .

Daya ingat seorang siswa harus kuat agar siswa itu mampu menerima pelajaran menyimpannya dan mengeluarkannya ketika ia membutuhkan. Pada kenyataannya siswa sering mengalami kegagagalan atau kesulitan dalam mengingat pelajaran yang telah lalu baik hal itu disebabkan oleh beberapa faktor.Siswa yang mengalami kesulitan belajar pelu diberikan perhatian oleh konselor sekolah. Gangguan-gangguan yang terjadi itu bisa disebabkan karena inagtan yang dimilikinya sedikit atau karena sebuah gangguan lainnya. Oleh karena itu konselor di sekolah harus mampu meningkatkan daya ingat belajar siswa.

Peran konselor meningkatkan dalam meningkatkan daya ingat ini dapat juga dilakukan dengan layanan-layanan yang ada di bimbingan dan konseling.Prayitno \& Amti, (2009) layanan-layanan dalam bimbingan dan konseling terdiri dari (1) layanan orientasi (2) layanan informasi (3) layanan penempatan dan penyaluran (4) layanan penguasaan konten (5) layanan konseling peroangan (6) layanan bimbingan kelompok (7) layanan konseling kelompok.

\section{KESIMPULAN}

Konselor sangat berperan kepada siswa yang mengalami daya ingat yang rendah dalam belajar diamana apabila seorang siswa yang mengalami daya ingta yang rendah maka siswa terebut akan mengalami hasil belajar yang rendah, oleh karena iu konselor perlu membantu siswa dalam meningkatkan daya ingat siswa dengan cara mengidentifikasi siswa yang memiliki daya ingta yang endah dan 
memberikan latihan-latihan bagi siswa yang mengalami daya ingta yang rendah sehingga hal tersebut tidka mempengaruhi hasil belajar siswa terebut.

\section{REFERENCES}

Ahmadi, A. (2009). Psikologi Umum. Jakarta: Rieneka Cipta.

Davidoff, L. L. (1988). Psikologi Suatu Pengantar. (Juniati. M, Ed.). Jakarta: Erlangga.

Fudyartanta, K. (2011). Psikologi Umum. Yogyakarta: Pustaka Pelajar.

Hamalik, O. (2011). Psikologi Belajar. Jakarta: Bumi Aksara.

Hanafy, M. S. (2014). Konsep Belajar dan Pembelajaran. Lentera Pendidikan: Jurnal Ilmu Tarbiyah dan Keguruan, 17(1), 66-79.

Hartono., \& Boy, S. (2012). Psikologi Kelompok. Jakarta: Kencana.

Prayitno \& Amti, E. (2009). Dasar-dasar Bimbingan dan Konseling. Jakarta: Rieneka Cipta.

Slameto. (2010). Belajar dan Faktor-faktor yang Mempengaruhinya. Jakarta: Rieneka Cipta.

Soemanto, W. (1990). Psikologi Pendidikan. Jakarta: Rieneka Cipta.

Sujanto, A. (2014). Psikologi Umum. Jakarta: Bumi Aksara.

Syah, M. (2007). Psikologi Pendidikan dengan Pendekatan Baru. Jakarta: Rieneka Cipta.

Uno, H. B. (2012). Teori Motivasi dan Pengukurannya. Jakarta: Bumi Aksara. 